\title{
Design and Construction of a Telescopic Platform
}

\author{
Akinnuli Basil Olufemi ${ }^{1}$, Olabaniji Taye Sola ${ }^{2}$, Yakubu Anakobe Jimoh ${ }^{3}$ \\ ${ }^{1}$ Department of Production and Industrial Engineering, Federal University of Technology, Akure, Nigeria \\ ${ }^{2}$ Department of Mechanical Engineering, Landmark University, Omu-Aran, Nigeria \\ ${ }^{3}$ Department of Computer Engineering, Federal Polytechnic Ile, Oluji, Nigeria \\ Email: ifembola@yahoo.com,yakubqiblah@yahoo.com
}

How to cite this paper: Olufemi, A.B., Sola, O.T. and Jimoh, Y.A. (2018) Design and Construction of a Telescopic Platform. Open Access Library Journal, 5: e4784. https://doi.org/10.4236/oalib.1104784

Received: July 16, 2018

Accepted: September 26, 2018

Published: September 29, 2018

Copyright $\odot 2018$ by authors and Open Access Library Inc.

This work is licensed under the Creative Commons Attribution International License (CC BY 4.0).

http://creativecommons.org/licenses/by/4.0/

(c) (i) Open Access

\begin{abstract}
A telescopic platform is equipment used in the Laboratory or Workshop to carry out different kinds of job on the ceiling e.g. fixing or replacing of electric bulbs, fixing of electric fans etc. it is also used to change streetlight on campus. Now that technology changes rapidly, the use of step ladders of different kinds with low reliability and quite a number of limitations should gradually be replaced by less expensive alternative. To this end, Telescopic Platform has been designed and constructed to meet the urgent need for replacement. Materials were locally sourced for such as Bevel gear, Sprockets, Chain, Power screw, Nut etc. and used for the fabrication, which involves welding grinding, fitting practices as well as assembly. The Telescopic Platform so produced is mobile, suitable for use on flat, sloping and terraced surfaces with high reliability. Its height can be varied within a range designed. The telescopic platform designed can offer a good capacity of $834 \mathrm{~N}$ with efficiency of $85 \%$ and can conveniently carry an average human weight of $736 \mathrm{~N}$.
\end{abstract}

\section{Subject Areas}

Industrial Engineering, Mechanical Engineering

\section{Keywords}

Telescopic, Platform, Stepladder, Design, Fabrication, Mechanical Elements

\section{Introduction}

The convectional platform or stepladder for internal use within building has a few imitations. It can only be used on plane surfaces. It becomes unstable on a slope or a terraced floor. Moreover, the stepladder is of fixed height. If such a 
platform is to be built for changing the light bulbs in a workshop which is 6.5 metres high, it will be too big for easy movement and storage. As a result of these limitations, the telescopic platform is designed such that it can be used on a plane, a sloping as well as a terraced floor. Unlike the stepladder, the platform level is adjustable. The platform can therefore be set for use at various heights. At its lowest height it is handy for ease of storage and movement.

Other devices in the same category with telescopic platform include jack which is portable hand operated device for raising heavy weight through short distances, exerting great pressure, or holding assembled work firmly in position, as in jacking up a building to prevent settling or keep in position while replacing a foundation [1]. The jack's effectiveness stems from the ratio of the load or weight of the object raised to the amount force applied to the handle of the jack. The ratio can be made quite high by the use of a gear or screw to regulate the upward extension of the jack. A ratchet allows a heavy weight to be raised in short successive stages, with jack locking whenever force is not being applied to its handled. Though limited in capacity by the requirement of portability and ease of manual operation, a jack may be viewed to lift, or exert a force of several tonnes [2].

Another example is a crane, which is a device that not only lifts heavy objects but also shifts them horizontally. Cranes are distinct from hoists, passenger elevators and other devices intended solely or primarily for vertical lifting and from conveyors, which continuously lift or carry bulk materials such as grain and coal. Cranes have come into their present widespread application only since the introduction of steam engines, internal combustion engines, and electric motors beginning in the nineteenth century [3]. The most prominent of that class known as Derrick cranes is the jib, or boom; this is a long beam that is structurally reinforced so that it will not bend. The jib is supported or held aloft by guy wires running from its top to its vertical mast or pillar that is itself stiffly braced; the guy wires set the angle at which the jib leans. The load may also be moved from side to side by having the jib pivot or rotate on its base around the pivot, [4].

\section{Literature Review}

Conveyor is any or various device that provides mechanized movement of materials, as in a factory; they are used primarily in industrial applications but also in large farms, in warehousing and freight handling, and in movement of raw materials. Conveyor may be only a few inches in length, or they may be integrated systems several miles long [3]. During the 1960s, air-float conveyors were introduced consisting of a platform, or pallets, equipped with air jet underneath to provide levitation. Thus, the supported platform can be easily moved in any direction over a flat surface [4]. Belt conveyors or fabric, rubber, plastic, leather or metal are driven by a power-operated roll mounted underneath or at one end of the conveyor. The floor conveyor uses chain, cable or other linkage mounted in 
or close in an endless track. They are usually designed to drag the train of a four-wheeled art around in loop to carry large products or materials for assembly on the conveyor system [5]. Slat conveyors consists of endless chains, driven by electric motors operating through reduction gears and sprockets, with attached spaced slats to carry objects that will damage a bolt because of sharp edges or heavy weight, Britannica [4].

Most modern elevators are propelled by electric motors with the aid of a counterweigh, through a system of cables and pulleys by opening a decisive role in a characteristic urban geography of many modern cities especially in United State, and promises to fill aim indispensable role in future city developments. The practice of lifting load by mechanical means during building operations goes to at least Roman architect-engineer Vitrullius in the 1st century BC described lifting platforms that use pulleys and capstans, or windlasses, operated by human, animal, or water power. Steam power was applied in such devices in England by 1800 [6]. In the early 19th centuries the hydraulic lift was introduced, in which a platform was attached to a plunger in a cylinder sunk in the ground below the shaft to a depth equal to the shaft's height. Pressure was applied to the fluid in a cylinder by a steam pump. Later a combination of pulley was used to multiply car's motion and reduced the depth of the plunger. All these devices employed counterweight to balance the weight of the car, requiring only enough power to raise the load [7]. Prior to the mid-1850s, these principles were primarily applied to freight hoists. The poor reliability of the ropes used at that time made such lifting platform unsatisfactory for passenger's case. When an American Elisha Graves Otis, introduced a safety device in 1853, he made the passenger elevator possible. Otis device, demonstrated at the Crystal Palace Exposition in New York, incorporated a clamping arrangement that gripped the guide rails on which the car moved when tension was released from the hoist rope. The first passenger elevator was put into service in the Haugh Wout Department Store in New York City in 1857; driven by steam power, it climbed five stories in less than a minute and was pronounced success [8].

With the safety, speed and height problems overcome, attention was turned to convenience and economy. In 1915, so called automatic leveling was introduced in the form of automatic controls at each floor that took over when the operator short off his manual control within a certain distance from the floor level and guided the car to a precisely positioned stop. Power control of door was added. With increase building height, elevator speed increased to 365 metres per minute is such installations as those for the upper levels of the Empire State Building (1931) and reached 549 metres per minute in the John Hancock center, Chicago in 1970 [9]. Modern elevators are made in variety of types for many purposes; in addition to ordinary freight and passenger operations. They are used in Ships, dam and such specialized structures as rocket launchers, heavy lift, rapid-descent elevator are employed in high-rise construction operations. Practically all are electrically propelled, either by cable, pulley and counterweight, by a widen drum mechanism or by an electro hydraulic combination. Multiple cables (3 or 
more), increase both the fraction surface with pulley and safety factor, cable failure is rare [6]. The safety, usually mounted below car platform, is actuated by a speed governor through a rope. The rope pulls the safety to the on position in the event of excessive downward motion of the car. The device first cuts off elevator power; if excessive speed continues, it applies the safety break [10]. Elevators lifted by hoisting ropes are required to have platform "safeties" devices designed to clamp unto the steel guide rails upon activation, quickly breaking the elevator to a halt. Now that the technology changes rapidly, the use of step ladders of different kinds with low reliability and quite a number of limitations should gradually be replaced by less expensive and more reliable alternatives.

\section{Materials and Methods}

\subsection{Identification of the Required Components}

The following components were required for the production of telescopic platform:

1) The screw pair

2) Bevel gear

3) Chain drives

The materials required for the production of the components of this telescopic platform are as shown in Table 1 .

Table 1. Selected components and reason for selection.

\begin{tabular}{|c|c|c|c|c|}
\hline$S / n$ & Component & Possible & Selected & Reason for selection \\
\hline & $\begin{array}{l}\text { Screw Gear } \\
\text { Top baring } \\
\text { stand power } \\
\text { screw nut }\end{array}$ & $\begin{array}{l}\text { Mild steel } \\
\text { Mild steel } \\
\text { Mild steel } \\
\text { Mild steel }\end{array}$ & & $\begin{array}{c}\text { Can be rolled or drawn, high } \\
\text { ductility and good heat treatment } \\
\text { and cold working, readily weldable, } \\
\text { low strength, high ductility, } \\
\text { hardenable by surface hardening } \\
\text { process, readily formed into intricate } \\
\text { shape because of its low carbon, good } \\
\text { heat treatment and cold } 110 \text { - } 150 \\
\text { brinel } 110 \text { - } 150 \text { elongation of } \\
25 \%-40 \% \text { can be rolled. }\end{array}$ \\
\hline 2 & $\begin{array}{l}\text { Sol plate } \\
\text { Floorplate } \\
\text { Shin cover }\end{array}$ & $\begin{array}{l}\text { Galvanized } \\
\text { Metal sheet }\end{array}$ & & $\begin{array}{l}\text { Excellent corrosion, water and oil } \\
\text { from shaft deflection frame } \\
\text { distortion, properties. }\end{array}$ \\
\hline 3 & Bearing & $\begin{array}{l}\text { High carbon } \\
\text { chromium steel } \\
\text { (self-aligning: and } \\
\text { internally sealed) }\end{array}$ & & $\begin{array}{l}\text { Compensate for misalignment } \\
\text { arising from shaft deflection frame } \\
\text { distortion, or foundation deflection. }\end{array}$ \\
\hline 4 & Sprocket & Iron & & $\begin{array}{l}\text { High compressive strength, good } \\
\text { damping characteristics, high } \\
\text { torsional strength, low notch } \\
\text { sensitivity, low tensile strength, good } \\
\text { casting properties, good anti-friction } \\
\text { properties, good machineability } \\
\text { and rigidity. }\end{array}$ \\
\hline
\end{tabular}




\subsection{Components Design Analysis}

\subsubsection{Design Analysis of the Screw}

Capacity of platform $=1000 \mathrm{~N}$.

Maximum load on screw $=1500 \mathrm{~N}$. Moment of inertia

$$
I=\frac{\pi d_{c}^{4}}{64}
$$

The crippling load required

$$
P=\frac{\pi^{2} E I}{4 L^{2}}=\frac{\pi^{3} E d_{c}^{4}}{256 L^{2}}
$$

The core diameter of screw is $28 \mathrm{~mm}$.

Therefore designing for screw of $28 \mathrm{~mm}$ core diameter, selection was made from the table of basic dimensions for square threads in $\mathrm{mm}$. (normal stress according to IS 4694-1968): Major diameter, $\left(d_{0}\right)=34 \mathrm{~mm}$; pitch $(p)=6 \mathrm{~mm}$ and mean diameter, $d_{m}=31 \mathrm{~mm}$ of screw were selected.

\subsubsection{Design Analysis for Nut}

$P=6 \mathrm{~mm} ; d_{o}=34.5 \mathrm{~mm} ; D=55 \mathrm{~mm} ; H=3.0 \mathrm{~mm} ; L=3 p ;(18 \mathrm{~mm}) \theta=5.70 \mu=$ $0.1=\tan \theta, \alpha=10.47^{\circ}$ Efficiency of screw $(\eta)$

$$
\begin{gathered}
\eta=\frac{\tan \alpha}{\tan (\alpha+\theta)} \\
\eta=63.7 \%
\end{gathered}
$$

Design analysis for the force $(P)$ and Torque $(T)$ of the screws with mean diameter $\left(d_{m}\right) 31 \mathrm{~mm}$. Horizontal force at the screw thread.

$$
\begin{gathered}
P=w \tan (\alpha+\theta) \\
P=870 \mathrm{~N}
\end{gathered}
$$

Torque at the Screw

$$
\begin{aligned}
& T=P_{r}=\left(P \times \frac{d_{m}}{2}\right) \\
& T=13485 \mathrm{~N} \cdot \mathrm{mm}
\end{aligned}
$$

\subsubsection{Design for Stress}

Compressive stress on the screw cross-section

$$
\begin{gathered}
\sigma_{c}=W / A \\
\sigma_{c}=4.872 \mathrm{~N} / \mathrm{mm}^{2}
\end{gathered}
$$

where $W$ is the designed load on the screw and $A$ is the area of the screw shaft.

\subsubsection{Torsion Stress $(\tau)$}

$$
\begin{gathered}
\tau=\frac{T_{r}}{J} \\
\tau=3.129 \mathrm{~N} / \mathrm{mm}^{2}
\end{gathered}
$$


Maximum Shear due to combined torsion and direct stresses $\left(\tau_{m}\right)$

$$
\begin{gathered}
\tau_{m}=\left\{\frac{1}{2}\left(\sigma_{c}^{2}+4 \tau^{2}\right)\right\}^{1 / 2} \\
\tau_{m}=3.965 \mathrm{~N} / \mathrm{mm}^{2}
\end{gathered}
$$

To check the screw thread for bearing, shear and bending stresses, bearing pressure on screw thread must be equal to that on the nut thread. Allowing a bearing pressure of $0.8 \mathrm{~N} / \mathrm{mm}^{2}$ on the nut thread, shear stress on screw thread, $\left(\tau_{s}\right)$

$$
\begin{gathered}
\tau_{s}=\frac{W}{2 \pi r_{c} n h} \\
\tau_{s}=0.874 \mathrm{~N} / \mathrm{mm}^{2}
\end{gathered}
$$

\subsubsection{Determination of Bending Stress}

$$
\sigma_{b}=\frac{3 W L}{2 \pi r n h^{2}}=2.37 \mathrm{~N} / \mathrm{mm}^{2}
$$

\subsubsection{Design Analysis of Gear Box}

The arrangement in the gearbox is as shown in Figure 1. Pair of standard sizes of straight bevel gears was used and the bearing was also selected from standard sizes.

Specification:

Velocity ratio $V \cdot R(5: 3)$

Pinion diameter,

$D_{P}(60 \mathrm{~mm})$

Ear diameter, $D_{g}(100 \mathrm{~mm})$

Face width, $b(25 \mathrm{~mm})$

Material (Steel)

Gear torque $T_{g}=$ Torque at Screw/Efficiency of Screw

$$
T_{g}=21170 \mathrm{~N} \cdot \mathrm{mm}
$$

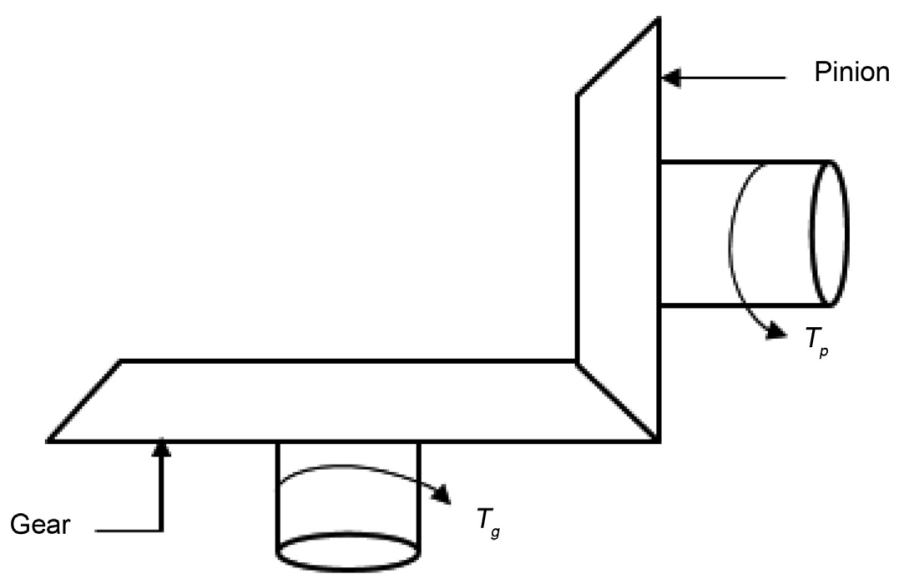

Figure 1. Torque. 
Pinion torque $T_{P}=T_{g} \times \frac{D_{P}}{D_{g}}$

$$
T_{P}=12700 \mathrm{~N} \cdot \mathrm{mm}
$$

\subsubsection{Design Analysis for Chain}

For the velocity ratio (V.R)

$$
\begin{gathered}
V . R=\frac{\text { Pinion revolution per minute }}{\text { Manual turning per minute }} \\
V . R=\frac{104.17}{50}=2.1
\end{gathered}
$$

Chain and sprockets selection (Holowenko, 1983)

For driven Sprocket:

$N_{t 2}=18 ; P=14 \mathrm{~mm}$

The Pitch dameter, $D_{2}=\frac{2 N_{t 2} P}{2 \pi}$

$$
D_{2}=80.2 \mathrm{~mm}
$$

For driver wheel:

$N_{t 1}=40$; Pitch, $P=14 \mathrm{~mm}$

The Pitch dameter, $D_{1}=\frac{2 N_{t 1} P}{2 \pi}$

$$
D_{1}=178.25 \mathrm{~mm}
$$

The Velocity ratio, V.R

$$
\begin{gathered}
V . R=\frac{\text { Output Speed, } n_{2}}{\text { Input Speed, } n_{1}}=\frac{N_{t 1}}{N_{t 2}} \\
V . R=2.22
\end{gathered}
$$

For the roller chain

Pitch, $P=14 \mathrm{~mm} ; d=5 \mathrm{~mm} ; N=5 \mathrm{~mm}$

Therefore chain length $L$

$$
\begin{gathered}
L=2 C+\pi\left(R_{1}+R_{2}\right)+\frac{\left(R_{1}+R_{2}\right)^{2}}{C} \\
L=2808 \mathrm{~mm}
\end{gathered}
$$

Torque required at pinion $\left(T_{p}\right)$ taking efficiency to be $90 \%$ Torque at the driven sprocket,

$$
\begin{gathered}
T_{P}=T_{d n} \cdot \frac{D_{1}}{D_{2}} \\
T_{P}=31360 \mathrm{~N} / \mathrm{mm}
\end{gathered}
$$

Torque required of handle with length $180 \mathrm{~mm}(L)$

$$
\begin{gathered}
\tau_{h}=\frac{\tau d r}{L} \\
\tau_{h}=175 \mathrm{~N}
\end{gathered}
$$




\subsubsection{Design Analysis for Shaft and Base}

The shaft is fully supported by the base of the platform so that it is not under much stress. The shaft was manufactured from solid drawn steel tubing to the following specification;

Inside diameter, $D_{1}=55.0 \mathrm{~mm}$; Outside diameter, $D_{2}=65 \mathrm{~mm}$; Length, $L=$ $2400 \mathrm{~mm}$.

The support legs of the platform were made from steel rods. Step ladder was attached to one of the legs to enable the operator climb unto the platform.

\subsection{Determination of Stress on the Cross-Section of the Support Legs}

The support legs are attached to the shaft through flange ball bearings to allow for the rotation of the legs around the shaft. Weight of platform plus load on platform $(W)(4000 \mathrm{~N})$.

The direct load on the Cross-section of the support legs. Since there are four legs, therefore;

$$
\begin{gathered}
4 \cos \theta=\frac{W_{T}}{F} \\
F=\frac{W_{T}}{4 \cos \theta} \\
F=1000\left(4 \cos 29.36^{\circ}\right)=1147.4 \mathrm{~N}
\end{gathered}
$$

Direct stress on the Cross-Section of the support legs

$$
\sigma=\frac{F}{\pi d^{2} / 4}=3.65 \mathrm{~N} / \mathrm{mm}^{2}
$$

\subsection{Design Analysis of the Jack}

The jacks were manufactured to the following specifications; minor diameter $d_{m}$ (14.60 mm); normal diameter $d_{n}(19.10 \mathrm{~mm})$; length, $L(300 \mathrm{~mm})$ and material selected was made from $0.25 \mathrm{C}$ steel.

The pressure plate was made from Cast iron and the screw attached to it through a ball and socket joint to allow for self-alignment.

Compressive stress of the screw cross-section.

Total weight of platform plus load $W_{T}=4000 \mathrm{~N}$ compressive stress on screw.

Cross-Section

$$
\sigma_{c}=\frac{W_{T}}{\pi d_{c}^{2} / 4}=\frac{4 \times 4000}{\pi \times(14.6)^{2}}=23.893 \mathrm{~N} / \mathrm{mm}^{2}
$$

This stress is sufficiently low compared to the Ultimate compressive stress of $430 \mathrm{~N} / \mathrm{mm}^{2}$.

\subsection{Machine Production}

The materials used in the construction were obtained from various sources. The power screw, gearbox, nut, bevel gear, shaft and other parts of the materials were 
bought from the market.

The major work done in the construction were cutting, filing and welding. There was very little machining. The construction process is as follows:

The nut was screwed into the power screw, which had already been attached to the gear box. The stopper was then machined to slide into the power screw and to just slide into the shaft. It was then welded to the end of the screw.

1) Sliding the stopper and screw down the shaft the nut was brought into position at the upperpart of the shaft welded.

2) The platform was fixed on top of the gearbox and the gear made from steel rod fixed to the top of the platform.

3) The Chain drive was then assembled as specified in the design.

\subsection{Production Cost}

These costs include material cost, direct labour cost and overhead cost. All of these costs were incurred during the equipment fabrication stage.

\subsection{Material Cost}

The cost of raw materials purchased for the fabrication of the machine (Tables $2-4)$.

Table 2. Cost of materials.

\begin{tabular}{|c|c|c|c|c|c|c|}
\hline $\mathrm{S} / \mathrm{n}$ & Component & Material & Specification & Quantity & $\begin{array}{l}\text { Unit } \\
\text { price } \\
\text { (N) }\end{array}$ & $\begin{array}{l}\text { Amount } \\
\text { (N) }\end{array}$ \\
\hline 1 & Floor plate & Mild steel & $700 \times 500 \mathrm{~mm}$ & 1 & 1500 & 1500 \\
\hline 2 & Chain cover & Mild steel & $900 \mathrm{~mm}$ & 1 & 1200 & 1200 \\
\hline 3 & Chain & & $800 \mathrm{~mm}$ & 1 & 500 & 500 \\
\hline 4 & Bearing "small" & Cast iron & $\Theta 60$ & 4 & 600 & 2400 \\
\hline 5 & Bearing "big" & Cast iron & Ө 150 & 1 & 1500 & 1500 \\
\hline 6 & Top bearing & Steel & $1000 \mathrm{~mm}$ & 1 & 500 & 500 \\
\hline 7 & Power screw & Mild steel & $1750 \mathrm{~mm}$ & 1 & 1500 & 1500 \\
\hline 8 & Big nut & Bronze & 460 & 1 & 500 & 500 \\
\hline 9 & Gear box & Mild steel & & 1 & 1000 & 1000 \\
\hline 10 & Bevel gear & Mild steel & $\Theta 350 \times \Theta 200$ & 2 & 1000 & 1000 \\
\hline 11 & Sole plate & Mild steel & & 1 & 300 & 300 \\
\hline 12 & Shaft & Mild steel & $2300 \mathrm{~mm}$ & 1 & 7000 & 7000 \\
\hline 13 & Supporting leg & Steel & $2500 \mathrm{~mm}$ & 4 & 500 & 2000 \\
\hline 14 & Brazing & Steel & $100 \mathrm{~mm}$ & 4 & 250 & 1000 \\
\hline 15 & Ladder & Steel & $1500 \times 200 \mathrm{~mm}$ & 1 & 2000 & 2000 \\
\hline 16 & Big sprocket & Cast iron & $\Theta 400$ & 1 & 1200 & 1200 \\
\hline 17 & Small sprocket & Cast iron & $\Theta 100$ & 1 & 700 & 700 \\
\hline \multirow[t]{2}{*}{18} & Guide rail & Steel & & 6 & 400 & 2400 \\
\hline & & & Total & & & 32,000 \\
\hline
\end{tabular}


Table 3. Direct labour and fabrication cost.

\begin{tabular}{cccccc}
\hline S/n & Component & Description & Quantity & $\begin{array}{c}\text { Unit price } \\
(\mathrm{N})\end{array}$ & $\begin{array}{c}\text { Amount } \\
(\mathrm{N})\end{array}$ \\
\hline 1 & Guide rail & $700 \times 500 \mathrm{~mm}$ & 1 & 1000 & 1000 \\
2 & Chain cover & $900 \mathrm{~mm}$ & 1 & 750 & 750 \\
3 & Ladder & $800 \mathrm{~mm}$ & 1 & 1000 & 1000 \\
4 & Supporting leg & $2500 \mathrm{~mm}$ & 4 & 750 & 3600 \\
5 & Assembly & & & 3000 & 3000 \\
& miscellaneous & & & $\mathbf{8 7 5 0}$ \\
\hline
\end{tabular}

Table 4. Telescope stand.

\begin{tabular}{ccc}
\hline S/N & Description & Quantity \\
\hline 1 & Turning handle & 1 \\
2 & Big and small & 1 each \\
3 & Rail guide & 6 \\
4 & Rail guide & 8 \\
5 & Floorplate & 1 \\
6 & Chain cover; chain & 1 each \\
7 & Bearing "small" & 4 \\
8 & Bearing "big" & 1 \\
9 & Top bearing stand & 1 \\
10 & Power bolt & 1 \\
11 & Big nut & 1 \\
$12^{\mathrm{a}, \mathrm{b}}$ & A pair of bevel gear & 1 \\
13 & Platform & 1 \\
14 & Sole plate & 1 \\
15 & Upright stand & 1 \\
16 & Supporting leg & 4 \\
17 & brazing & 4 \\
18 & ladder &
\end{tabular}

\section{Cost Summary}

Material Cost $=\$ 32,200$

Fabrication Cost $=\$ 8750$

Overhead Cost $=\$ 10,000$

Grand Total $=\$ 50,950$

\section{Results and Discussions}

The telescopic platform designed offers a good capacity of $834 \mathrm{~N}$ which can conveniently support an average human weight of $736 \mathrm{~N}$. The height of the equipment is $6.2 \mathrm{~m}$ and thus it can be used to change the streetlights on campus 
and also in the workshops. As concerned farm harvesting of fruits and trimming of palm front leaves, this can serve these purposes. The production cost of this telescope platform is $\$ 50,950$ which is $\$ 141.53$ US Dollar using the current exchange rate of $\$ 360$ per Dollar.

The efficiency of the machine can be calculated below:

$$
\text { Efficency }=\frac{\text { Average capacity of machine } \times \text { adjustment factor }}{\text { Average human weight }} \times 100=85 \%
$$

The telescopic platform has an average efficiency of $85 \%$ which can give a reasonable performance in use.

\section{Discussions}

The proposed Telescopic Platform has been successfully designed, fabricated and tested and found capable of lift and sustain a weight of $736 \mathrm{~N}$. But getting to a load of $800 \mathrm{~N}$, there was buckling developed by the supporting shaft as well as shear at some welding joints. The maximum load recommended on this platform is $750 \mathrm{~N}$ for safety assurance.

\section{Conclusion}

The design and construction of a telescopic platform had been carried out, and can meet the urgent need for the replacement of electric bulbs, and fixing of fans in the workshop. It can also be used for the erection of streetlights on campus; more so, it can meet the requirement of painting in high building as well as some activities as concerned harvesting of fruits, pruning of branches and removal of epiphytes.

\section{Recommendation}

Although this design satisfies the requirement of the purpose for which the platform is meant, considerable improvement can still be made in the following areas:

1) Operation: to save the operator the task of raising the platform manually, the platform can be redesigned such that the screw will be driven through the gars by an electric motor. This of course will increase the production cost.

2) Minimum platform level: it can be observed that the screw-pair principle employed in the design only serves to reduce the minimum platform level to about half the maximum level. This level is too high for compactness and storage when the platform is fully telescoped.

The minimum platform level can be reduced considerably by redesigning the platform using the strut and cylinder principles, in which the platform be raised or lowered by feeding hydraulic working fluid into hydraulic telescopic rams which will for the stalk of the platform. The working fluid can be fed to the rams by pumps which can be operated either manually or electrically.

Using this principle, the minimum platform level can be reduced to one-third of the maximum level. 


\section{Acknowledgements}

Authors hereby acknowledge the Head of Department of Industrial and Production Engineering of Federal University of Technology Akure, Nigeria; for release of found and the workshop tools required for the production of this product. Also we can not but appreciate Engr. J. O. Fasan the Technician that carried out the fabrication of this platform.

\section{Conflicts of Interest}

The authors declare no conflicts of interest regarding the publication of this paper.

\section{References}

[1] Knowlton, H.B. (1950) Introduction to Hardening of Gears. SAE January Journal, 3, 33-42.

[2] Laughlin, H.H. (1961) Calculation of Force Condition of a Loaded Connection. Machine Design. McGraw-Hill Book Co., New York, 213-250.

[3] Roth Bart, H.A. (1964) Mechanical Design and System Handbook. McGraw-Hill Book Co, New York, 176-178.

[4] McGraw Hill Inc. (2003) Encyclopedia Britannica. McGraw Hill Inc., New York, 211-214.

[5] Lipson, C., Noll G.C. and Clock, L.S. (1950) Selection of a Power Suitable Type of Chain. Stress and Strength of Manufactured Parts. McGrawhill, Inc., New York.

[6] Berezovsky, Yu., Chernilevsky, D. and Petrov, M. (1983) Simple Definition of Installed Shafts and Hollow Ones. Machine Design. Mir. Publisher, Moscow, 355.

[7] Faires, V.M. (1965) Design of Gearing for Exact Axis Distance. Design of Machine Elements. The Macmillan Company, New York, 37-70.

[8] Kalpakjian, S. and Schmid, S. (2006) Manufacturing Engineering and Technology. Pearson Education Inc., Upper Saddle River, 1246-1250.

[9] Budynas, N. (2008) Shigley's Mechanical Engineering Design. 8th Edition, McGraw-Hill Companies, New York, 15-351.

[10] Deutschland, A.D., Michel's W.J. and Wilson C.E. (1975) Design Calculation and Necessary Mounting Prestressing of the Connection and Fastening Torque. Machine Design Theory and Practice. Collior Macmillan Publishers, London, 300-302. 


\section{Nomenclature}

$\sigma_{c}=$ compressive stress $\left(\mathrm{N} / \mathrm{mm}^{2}\right)$

$\epsilon=$ young's modulus $\left(\mathrm{N} / \mathrm{mm}^{2}\right)$

$L_{s}=$ lead of the screws

$P=$ pitch of the thread

$I=$ moment of inertia

$L=$ unsupported length

$n=$ factor of safety

$W=$ design load $(\mathrm{N})$

$d_{c}=$ core diameter

$D_{o}=$ outside diameter $(\mathrm{mm})$

$d_{o}=$ major diameter of nut $(\mathrm{mm})$

$H=$ depth of thread (mm)

$\eta=$ Efficiency (\%)

$\theta=$ Friction angle $\left({ }^{\circ} \mathrm{C}\right)$

$\alpha=$ Helix angle

$\pi=$ constant

$d_{m}=$ Mean diameter

$\mathrm{T}=$ Torsion stress

$\mathrm{T}_{s}=$ Share stress

$\sigma_{b}=$ bending stress

$A=$ Area of the screw shaft $\left(\mathrm{mm}^{2}\right)$

$T=$ torque

$\mathrm{T}_{m}=$ Maximum share 